\title{
Long-term records of erosional change from marine ferromanganese crusts
}

\author{
R Keith O'NiOns* and MARTin Frank \\ Department of Earth Sciences, University of Oxford, Parks Rd., Oxford OX1 3PR, UK \\ *email: keith.onions@earth.ox.ac.uk
}

\begin{abstract}
Ferromanganese crusts from the Atlantic, Indian and Pacific Oceans record the $\mathrm{Nd}$ and $\mathrm{Pb}$ isotope compositions of the water masses from which they form as hydrogenous precipitates. The ${ }^{10} \mathrm{Be} /{ }^{9} \mathrm{Be}-$ calibrated time series for crusts are compared to estimates based on Co-contents, from which the equatorial Pacific crusts studied are inferred to have recorded ca. $60 \mathrm{Ma}$ of Pacific deep water history.

Time series of $\varepsilon_{\mathrm{Nd}}$ show that the oceans have maintained a strong provinciality in $\mathrm{Nd}$ isotopic composition, determined by terrigenous inputs, over periods of up to $60 \mathrm{Ma}$. Superimposed on the distinct basin-specific signatures are variations in $\mathrm{Nd}$ and $\mathrm{Pb}$ isotope time series which have been particularly marked over the last 5 Ma.

It is shown that changes in erosional inputs, particularly associated with Himalayan uplift and the northern hemisphere glaciation have influenced Indian and Atlantic Ocean deep water isotopic compositions respectively. There is no evidence so far for an imprint of the final closure of the Panama Isthmus on the $\mathrm{Pb}$ and $\mathrm{Nd}$ isotopic composition in either Atlantic or Pacific deep water masses.
\end{abstract}

\section{Introduction}

Tectonics and climate combine to influence the rates and mechanisms of rock weathering and erosion. However, details of their interrelationships are not well understood. Part of the problem is to identify records of the relevant changes that have taken place. Because a significant portion of the terrigeneous products of continental weathering and erosion enter the oceans and leave an imprint on the chemical and isotopic composition of seawater much effort has been devoted to the recovery of marine records of seawater composition.

Of particular interest have been records of the abundance and isotopic composition of metals in seawater. These are controlled primarily by the nature of their terrigeneous and hydrothermal sources on the one hand and their oceanic residence times on the other. As a consequence, different elements display quite different isotopic distribution patterns in the oceans. For example, despite the large variation in isotopic composition of the various $\mathrm{Sr}$ inputs into the ocean the ${ }^{87} \mathrm{Sr} /{ }^{86} \mathrm{Sr}$ ratio of seawater is uniform globally. This is because the oceanic residence time of $\mathrm{Sr}$ is ca. $2 \mathrm{Ma}(1 \mathrm{Ma}=1$ million years) and thus much longer than the ca. $1.5 \mathrm{ka}$ ocean circulation time ( $1 \mathrm{ka}=1,000$ years $)$. In contrast, $\mathrm{Nd}$ has a residence time very similar to the circulation time of the ocean and consequently shows significant differences in isotopic composition between the main ocean basins and even different water masses (e.g. Piepgras et al 1979). Thus at any one time the isotopic distribution pattern of metals in the oceans is a result of the interplay between the advection of the dissolved metal input by the circulation and their removal into the marine sediments. In principle it should be possible to reconstruct details of any time-dependent changes in the isotopic distribution patterns arising from either changes in the inputs (erosion and hydrothermal) and the ocean circulation from the marine sedimentary record.

Considerable progress has been made in reconstructing the distribution of $\mathrm{Nd}$ and $\mathrm{Pb}$ isotopes in Atlantic, Indian and Pacific Ocean water masses from hydrogenous ferromanganese crusts (hereafter called

Keywords. Ferromanganese crusts; Atlantic; Pacific; Indian Ocean; Nd and Sr isotopes; erosion. 
crusts), in some cases as far back as $60 \mathrm{Ma}$ ago (Goldstein and O'Nions 1981; Albarède and Goldstein 1992; Abouchami and Goldstein 1995; von Blanckenburg et al 1996a; b; Burton et al 1997; Christensen et al 1997; Albarède et al 1997; Ling et al 1997; Abouchami et al 1997; 1998). These metals have short oceanic residence times, similar to or shorter than the global circulation time, and therefore display a strong provinciality in their isotopic distribution. From these records it has been possible to assess the impact of changes in the balance of erosion products from different input sources to the oceans as well as changes in ocean circulation.

Crusts are widely distributed in the oceans and provide intact and often long-term records of $\mathrm{Nd}, \mathrm{Pb}$ and $\mathrm{Hf}$ isotopes from which water mass characteristics have been derived. This reconstruction has been facilitated by successful dating of the crusts using cosmogenic ${ }^{10} \mathrm{Be}$ (Segl et al 1984; Ling et al 1997; O'Nions et al 1998), which is introduced into the ocean after production in the upper atmosphere and scavenged from seawater by the Mn-Fe oxyhydroxides of which the crusts mainly consist. ${ }^{10} \mathrm{Be}$ chronologies have a practical limit of around $10 \mathrm{Ma}$ imposed by the 1.5 Ma half-life of ${ }^{10} \mathrm{Be}$. Linear extrapolation of the growth rates beyond $10 \mathrm{Ma}$ has resulted in maximum ages up to $60 \mathrm{Ma}$ (Ling et al 1997; O'Nions et al 1998) which has recently been supported by using a chronometer based on Co-contents (Frank et al 1999).

In this contribution the progress made in the use of well-dated crusts to reconstruct the $\mathrm{Nd}$ and $\mathrm{Pb}$ isotopic composition of ocean water masses over the last 10 to $60 \mathrm{Ma}$ will be reviewed. The importance of the changing balance of terrigeneous inputs into the ocean, particularly over the last $3 \mathrm{Ma}$ is summarised together with evidence for the apparently very limited response of the $\mathrm{Nd}$ - and $\mathrm{Pb}$-isotopic composition of deep water to the paleoceanographic changes related to the closure of the Panama Gateway over the last $10 \mathrm{Ma}$.

\section{Chronology of ferromanganese crusts}

The attempts to derive chronologies and growth rates for ferromanganese crusts have broadly been of three types based respectively upon in situ radioactive decay, Co-contents and ${ }^{87} \mathrm{Sr} /{ }^{86} \mathrm{Sr}$ ratios. The periods datable with the decay-based methods range from $300 \mathrm{ka}$ for ${ }^{230} \mathrm{Th}$ to approximately $10 \mathrm{Ma}$ for ${ }^{10} \mathrm{Be}$. The approach based on Co-content assumes a constant and known flux of Co to the crust growth surface and has theoretically no age limitations whereas the third method is based upon matching ${ }^{87} \mathrm{Sr} /{ }^{86} \mathrm{Sr}$ variations in the Mn-Fe-oxyhydroxide material of the crusts to the known global ocean ${ }^{87} \mathrm{Sr} /{ }^{86} \mathrm{Sr}$ evolution. Of these the $\mathrm{Sr}$ isotope approach although the subject of much careful work has been the least successful due to apparent isotope exchange (Burton et al 1997; Ling et al 1997; O'Nions et al 1998).

Hydrogenous ferromanganese crusts have growth rates typically in the range from 2 to $5 \mathrm{~mm} / \mathrm{Ma}$ but occasionally up to $15 \mathrm{~mm} / \mathrm{Ma}$ (cf. Segl et al 1984; Manheim 1986; Puteanus and Halbach 1988). Therefore the U-series based methods are useful only for the outer 1-2 mm of crusts but have been used widely (Segl et al 1984; Banakar and Borole 1991; Eisenhauer et al 1992; Chabaux et al 1995; 1997; Bollhöfer et al 1996; Abouchami et al 1997). Recent evidence for mobility of ${ }^{234} \mathrm{U}$ suggests that ${ }^{230} \mathrm{Th}$-based approaches are more reliable than U-based ones (Neff et al 1998). Methods for determining growth rates based on the decay of ${ }^{10} \mathrm{Be}$ have overall been the most successful for the period of the last $10 \mathrm{Ma}$ (Segl et al 1984; McMurtry et al 1994). In the Oxford laboratory we have used profiles of direct and high precision measurements of the ${ }^{10} \mathrm{Be} /{ }^{9} \mathrm{Be}$ ratio in crusts (Belshaw et al 1995) to determine their growth rates (Ling et al 1997; O'Nions et al 1998; Frank and O'Nions 1998). This method has the advantage of being independent of the amount of Be incorporated into the crust and succeeds because ${ }^{10} \mathrm{Be} /{ }^{9} \mathrm{Be}$ ratios in the oceans appear to have varied little over the last 5 to $10 \mathrm{Ma}$.

The Co-method in many cases provides a check on the uniformity of crust growth over the ${ }^{10} \mathrm{Be}$ dated intervals and the viability of extrapolated growth rates to deeper levels in the crust. The Co-method assumes a constant "rain rate" of Co to the growth surface of the crust and its concentration in the crust then depends upon the rate of addition of the other more abundant elements such as Fe and Mn. Thus as long as the "rain rate" has been constant the Co content will provide a reliable estimate of growth rate variations. The original calibration of the Co content as a chronometer was based on U-series dating of Co-rich crusts with Co contents $>1 \%$ from the central equatorial Pacific (Halbach et al 1983; Puteanus and Halbach 1988). An alternative relationship between Co-content and growth rate which is supposed to be applicable over a wider range of genetically different ferromanganese crusts and nodules and even pelagic sediments was developed by Manheim (1986).

Some of these aspects of crust chronology are illustrated here. In figure 1 the age-depth relationships obtained for crust D11-1 from the central equatorial Pacific based on ${ }^{10} \mathrm{Be} /{ }^{9} \mathrm{Be}$ ratios (Ling et al 1997) and Co contents (Frank et al 1999) are compared. The ages derived from the ${ }^{10} \mathrm{Be} /{ }^{9} \mathrm{Be}$ ratios suggest an average growth rate of $1.4 \mathrm{~mm} / \mathrm{Ma}$ between $7 \mathrm{Ma}$ ago and present and $2.7 \mathrm{~mm} / \mathrm{Ma}$ between 11 and $7 \mathrm{Ma}$ ago. Extrapolation of the latter suggests an age of about $58 \mathrm{Ma}$ at the base of the crust. The Co content measured by electron probe confirms that the growth rate has indeed deviated very little from the average growth rate of the uppermost $20 \mathrm{~mm}$ over the entire depth interval. The great value of the Co method is 

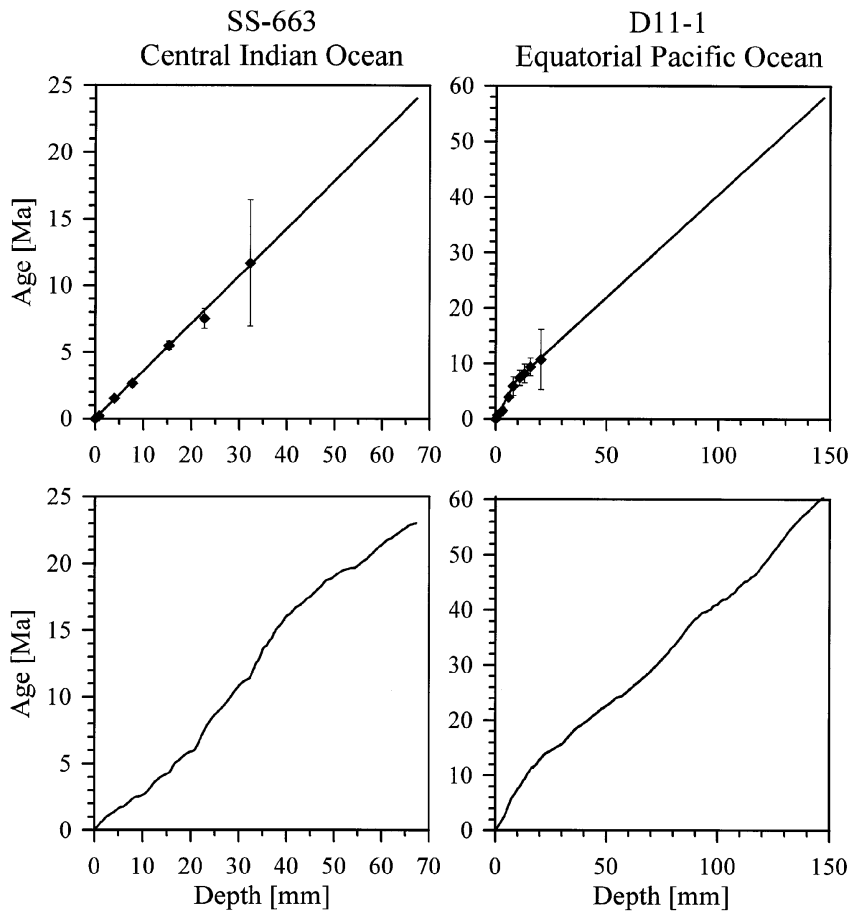

Figure 1. Comparison of age-depth relationships based on ${ }^{10} \mathrm{Be} /{ }^{9} \mathrm{Be}$ and Co-content chronometers for crusts SS-663 and D11-1 from the Central Indian and Pacific Ocean respectively. The upper diagrams show ages calculated from ${ }^{10} \mathrm{Be} /{ }^{9} \mathrm{Be}$ ratios assuming that the growth surfaces of the crusts have had the present day surface value during their growth and that the decrease in ${ }^{10} \mathrm{Be} /{ }^{9} \mathrm{Be}$ ratio with depth is due to decay of ${ }^{10} \mathrm{Be}$ (Ling et al 1997; O'Nions et al 1998). The lower diagrams show the age-depth relationships obtained from the Co-content chronometer (Frank et al 1999) using the relationships proposed by Manheim (1986) for SS-663 and by Puteanus and Halbach (1988) for D11-1. Note the excellent overall agreement between the two approaches and particularly the agreement between the Co-content age estimate and the extrapolated ${ }^{10} \mathrm{Be} /{ }^{9} \mathrm{Be}$ age estimates for D11-1.

the support it provides for the ${ }^{10} \mathrm{Be} /{ }^{9} \mathrm{Be}$ method and the justification for assuming that $60 \mathrm{Ma}$ of equatorial Pacific deep water history is recorded by this crust.

It should be recalled that there is an element of circularity in these age estimates. In the case of ${ }^{10} \mathrm{Be} /$ ${ }^{9} \mathrm{Be}$ ratios the age estimates assume that the ${ }^{10} \mathrm{Be} /{ }^{9} \mathrm{Be}$ ratio at the present-day growth surface is the same as that over the last $10 \mathrm{Ma}$. The self-consistent nature of the data supports this view but does not prove it. Similarly the claim of a uniform growth rate over the whole $150 \mathrm{~mm}$ of the crust assumes that the Co rain rate has been constant throughout and that there have been no hiati which is apparently supported by the good correspondence between the two approaches.

Self-consistent results from the ${ }^{10} \mathrm{Be} /{ }^{9} \mathrm{Be}$ ratio and Co-content chronometers as obtained for equatorial Pacific samples such as D11-1 (figure 1) are not found at all locations tested so far. The Co rain rate is not uniform everywhere in the ocean and appears to depend on the proximity to and intensity of the oxygen minimum layer; age models using the relationship of Puteanus and Halbach (1988) which were developed for Co-rich central Pacific seamount crusts are not directly applicable to other parts of the oceans. For Co-poor crusts anywhere else in the ocean the relationship of Manheim (1986) appears to be more suitable to estimate changes in growth rate (Frank et al 1999). The results for crust SS-663 from the central Indian Ocean (figure 1) provide an example of the application of the Co chronometer as adapted for crusts with low Co contents (Manheim 1986). The ${ }^{10} \mathrm{Be} /{ }^{9} \mathrm{Be}$ ratios obtained for SS-663 suggest a uniform growth rate for the crust over the outer $35-\mathrm{mm}$ and an age at the base of the crust close to $25 \mathrm{Ma}$ (Frank and O'Nions 1998). The Co-derived ages for this crust are in good agreement and also indicate an age between 20 and $25 \mathrm{Ma}$ at the base (Frank et al 1999). At present these are the only methods which have any general applicability and there is considerable merit in applying them in a complementary manner.

\section{Global pattern of $\mathrm{Nd}$ and $\mathrm{Pb}$ distribution}

The isotopic composition of seawater $\mathrm{Nd}$ varies as a function of water depth and water mass in the modern oceans as illustrated by published profiles of seawater $\varepsilon_{\mathrm{Nd}}$ from the Atlantic Ocean (figure 2). It also varies between ocean basins in a way that primarily reflects the age distribution pattern of the surrounding continental crust. At present seawater contains a large component of anthropogenic $\mathrm{Pb}$ but the pre-anthropogenic distribution also appears to reflect local provenance and residence time (von Blanckenburg et al 1996b). The surfaces of ferromanganese crusts and nodules from the Atlantic, Indian and Pacific Oceans have Nd isotope compositions, which obviously match those of the water masses in which they have grown (Albarède and Goldstein 1992; Abouchami and Goldstein 1995; Albarède et al 1997). They offer therefore the possibility that variations in the $\mathrm{Nd}$ and $\mathrm{Pb}$ isotope compositions of ocean water masses or changes in the pathways of water masses may be reconstructed from time series of ferromanganese crusts. In the case of the equatorial Pacific this may be back as far as $60 \mathrm{Ma}$ (Ling et al 1997; Frank et al 1999).

In order to reconstruct the $\mathrm{Nd}$ and $\mathrm{Pb}$ isotope composition of deep water at a particular location back through time it is necessary to acquire $\mathrm{Nd}$ and $\mathrm{Pb}$ isotope profiles on accurately dated crusts which are unaffected by diagenesis on the scale sampled for analysis. These conditions are apparently met for seven crusts from the Atlantic, Indian and Pacific Oceans and the results of $\mathrm{Nd}$ and $\mathrm{Pb}$ isotope analyses are displayed in figures 3 and 4 . These $\mathrm{Nd}$ and $\mathrm{Pb}$ isotope time series differ from those originally published (Ling et al 1997; Burton et al 1997; O'Nions et al 1998; Frank and O'Nions 1998) in that they use the modified age-depth relationships for three crusts (109D-C, BM1969.05, VA13-2) from Frank et al (1999). 


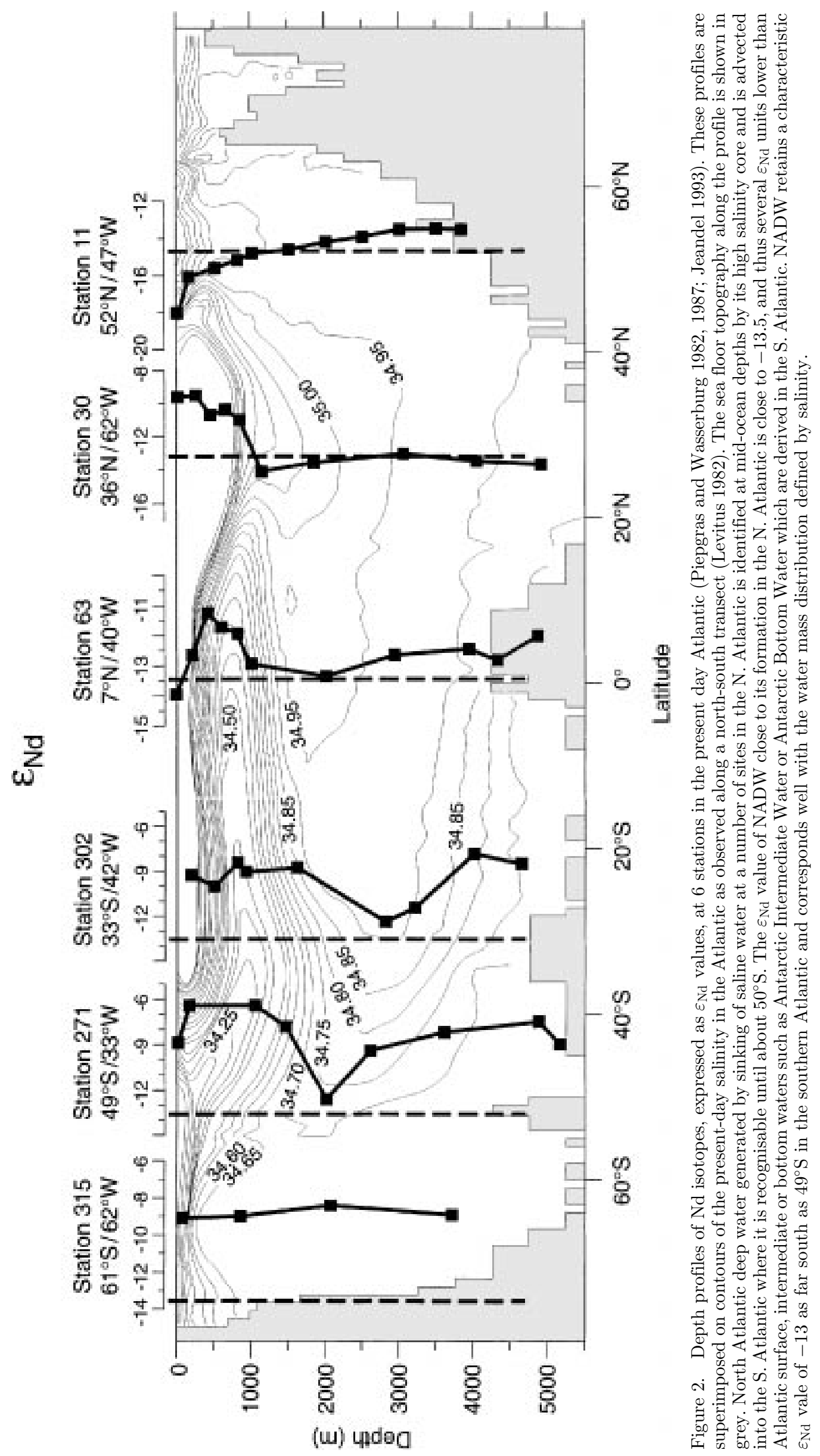




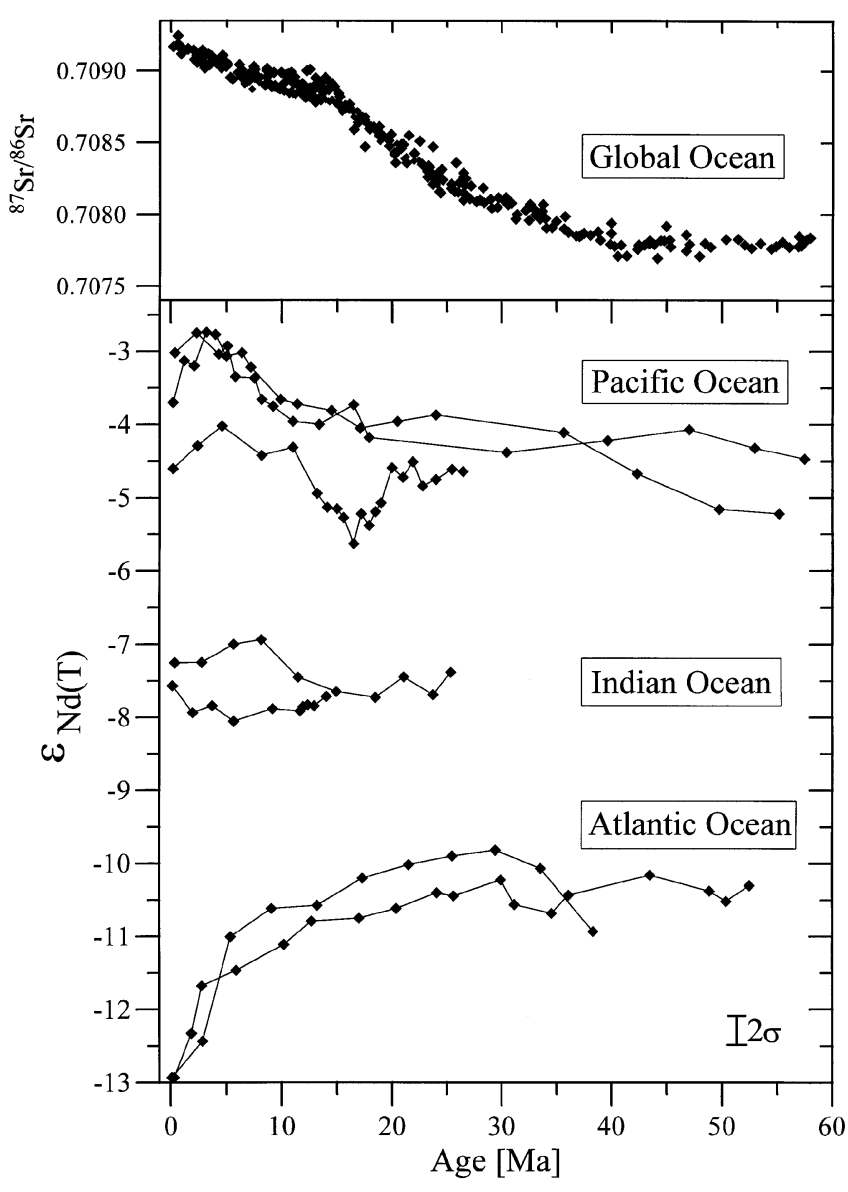

Figure 3. Comparison of $\varepsilon_{\text {Nd }}$ time series of ferromanganese crusts from the Atlantic, Indian and Pacific Oceans (Ling et al 1997; Burton et al 1997; O'Nions et al 1998) using the revised chronologies for SS-663, BM1969.05 and VA13/2 (Frank et al 1999). Note the strong inter-ocean provinciality of $\varepsilon_{\mathrm{Nd}}$, which is caused by the different overall $\varepsilon_{\mathrm{Nd}}$ value of the terrigeneous inputs into the ocean basins and the residence time of Nd which is similar to the ca. $1.5 \mathrm{ka}$ global ocean circulation time. This is too short for efficient mixing of $\mathrm{Nd}$ between the major ocean basins. These $\varepsilon_{\mathrm{Nd}}$ results are compared with the global ocean $\mathrm{Sr}$ isotope evolution derived from analyses of foraminifera (Koepnick et al 1985; DePaolo 1986; Hess et al 1986; Hodell et al 1991).

These authors have used Co-content profiles for each crust to identify changes in growth rate in those parts of the profiles which are beyond the range of ${ }^{10} \mathrm{Be} /{ }^{9} \mathrm{Be}$ dating. The most significant change compared to the originally published age-depth relationships was found for VA13-2 from the central Pacific (Segl et al 1984; Ling et al 1997), for which the Co content profile reveals a change from high growth rates around $13 \mathrm{~mm} /$ Ma prior to $14 \mathrm{Ma}$ ago to the lower rates of 3.75 and $2.3 \mathrm{~mm} /$ Ma determined by ${ }^{10} \mathrm{Be} /{ }^{9} \mathrm{Be}$ afterwards.

The $\mathrm{Nd}$ isotope time series in figure 3 reveal some remarkable features as follows:

- Although the mechanically sampled growth surfaces of the crusts represent $100 \mathrm{ka}$ or more of growth and integrate any variations in $\varepsilon_{\mathrm{Nd}}$ over this interval they are indistinguishable from those in their ambient water masses at the present day.

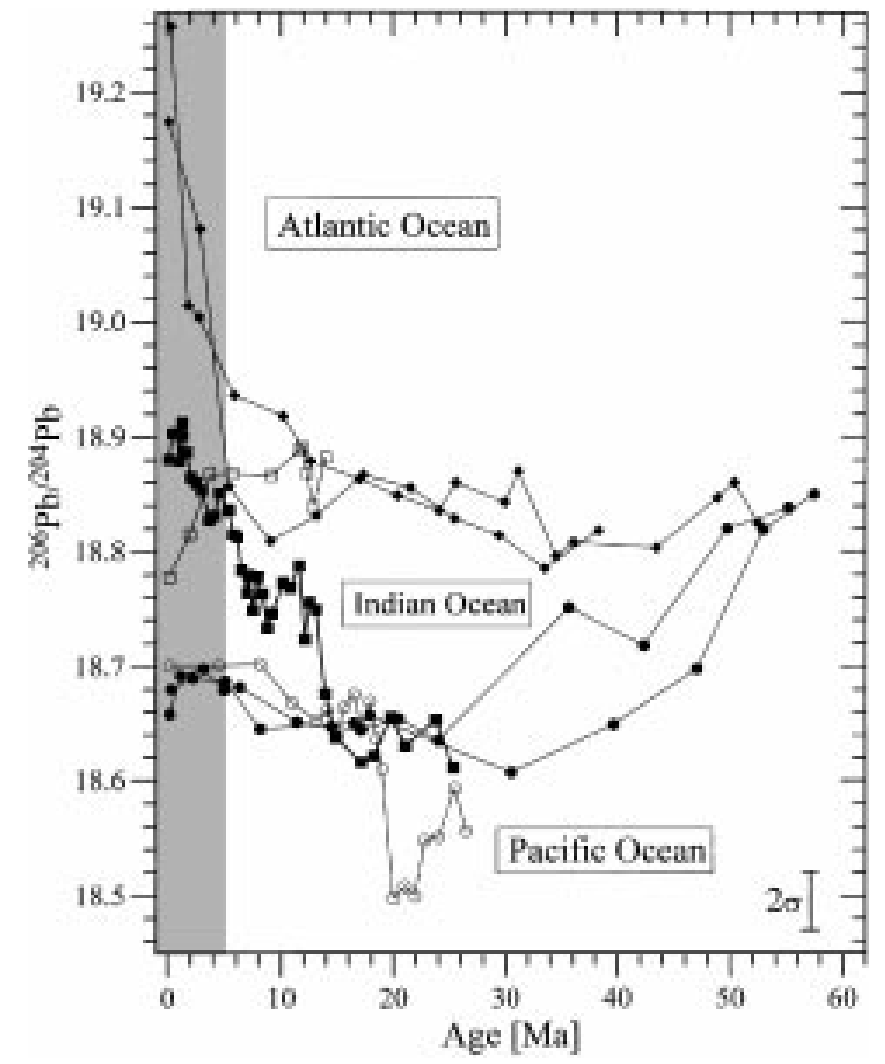

Figure 4. Comparison of ${ }^{206} \mathrm{~Pb} /{ }^{204} \mathrm{~Pb}$ time series of the same crusts as in figure 3. The North Atlantic crusts are marked by diamond symbols (Burton et al 1997; O'Nions et al 1998), the southern Indian Ocean crust by open squares (O'Nions et al 1998), the central Indian Ocean one by closed squares (Frank and O'Nions 1998), the Pacific deep water crust by open circles (Ling et al 1997) and the two Pacific seamount crusts by closed circles (Ling et al 1997). The shaded area highlights the last $5 \mathrm{Ma}$ over which separate Atlantic, Indian and Pacific Ocean signatures of the $\mathrm{Pb}$ isotopes in the deep water have apparently existed.

- For the last $20 \mathrm{Ma}$, and probably also the last $60 \mathrm{Ma}$, deep water masses in the Atlantic, Indian and Pacific Oceans have maintained separate identities in terms of $\varepsilon_{\mathrm{Nd}}$ values. These different identities reflect the $\varepsilon_{\mathrm{Nd}}$ values of the terrigeneous inputs into the three ocean basins which in turn reflect the age patterns of the surrounding continental crust. Thus, the more negative $\varepsilon_{\mathrm{Nd}}$ values in the Atlantic reflect the inputs from the old Precambrian cratons surrounding the N. Atlantic, whereas the much higher values in the Pacific have originated from the young volcanic arcs in the Pacific Ocean and its young continental margins.

- The equatorial Pacific deep water crust VA 13-2 was dredged from a depth of $4830 \mathrm{~m}$ compared with depths between 2400 and $1700 \mathrm{~m}$ for the other two Pacific seamount crusts. The $\varepsilon_{\text {Nd }}$ values of VA $13-2$ are lower than the other two crusts for the entire $26 \mathrm{Ma}$ record and suggest the long term presence of different water masses and stratification of $\mathrm{Nd}$ isotopes in the equatorial Pacific. 
- In addition to the long-term provinciality of $\mathrm{Nd}$ in the oceans there are superimposed shorter-term variations of $\varepsilon_{\mathrm{Nd}}$ in each of the records. These are most evident for the samples from the NW Atlantic where $\varepsilon_{\mathrm{Nd}}$ has decreased by about two units to reach the present day NADW value over the last few Ma. The records from the equatorial Pacific display smaller (less than $1 \varepsilon_{\mathrm{Nd}}$ unit) but significant decreases over the same time period. In the two Indian Ocean crusts only small and barely significant variations in $\varepsilon_{\mathrm{Nd}}$ occurred; slight increases of $0.5-0.7 \varepsilon_{\mathrm{Nd}}$ units are recorded in the southern Indian Ocean during the last $1 \mathrm{Ma}$ and in the central Indian Ocean at about $8 \mathrm{Ma}$ ago.

In addition to $\varepsilon_{\mathrm{Nd}}$ time series, $\mathrm{Pb}$ isotopes are also presented for Atlantic, Pacific and Indian Ocean samples again using the revised chronology of Frank et al (1999). These are displayed as ${ }^{206} \mathrm{~Pb} /{ }^{204} \mathrm{~Pb}$ ratios in figure 4. Because $\mathrm{Pb}$ has a residence time of 80-100 years in deep waters (Schaule and Patterson 1981) it is expected a priori to show a similar behaviour to that of $\mathrm{Nd}$, at least if processes occur on the basin scale. A comparison of the time series in figures 3 and 4 indeed shows similarities but also reveals major differences between $\mathrm{Pb}$ and $\mathrm{Nd} .{ }^{206} \mathrm{~Pb} /{ }^{204} \mathrm{~Pb}$ ratios, like $\varepsilon_{\mathrm{Nd}}$ values, show an inter-ocean provinciality for the last few $\mathrm{Ma}$, with well-resolved differences between the Atlantic, Indian and Pacific samples. Such differences have also existed for the other $\mathrm{Pb}$ isotope ratios (Frank and O'Nions 1998). Unlike the $\varepsilon_{\mathrm{Nd}}$ time series, however, ${ }^{206} \mathrm{~Pb} /{ }^{204} \mathrm{~Pb}$ ratios show much less provinciality further back in the past. This is particularly the case if the Atlantic and Pacific records are compared, which had a similar $\mathrm{Pb}$ isotope composition until about $50 \mathrm{Ma}$ ago and then started to diverge. The highlighted area in figure 4 emphasises the pronounced divergence in $\mathrm{Pb}$ isotopes over the last $5 \mathrm{Ma}$, much of which, as in $\varepsilon_{\mathrm{Nd}}$, is accounted for by variations in the N. Atlantic crusts.

\section{Records of continent erosion}

Weathering and erosion of continental crust is the dominant source of $\mathrm{Nd}$ in the oceans: the contribution from submarine hydrothermal sources was shown to be negligibly small in terms of mass balance (Michard et al 1983; Piepgras and Wasserburg 1985). Thus ferromanganese crusts bear a record of dissolved Nd of terrigeneous origin at their deep water growth sites over the last up to $60 \mathrm{Ma}$. The variations in $\varepsilon_{\mathrm{Nd}}$ at any particular site must reflect either changes in the $\varepsilon_{\mathrm{Nd}}$ of a particular input or its distribution by the ocean circulation. The effects of ocean circulation are at present substantial as evidenced by the advection of NADW with $\varepsilon_{\mathrm{Nd}}=-13.5$ from the sites of NADW generation in the North Atlantic into the southern Atlantic Ocean (figure 2).
The major part of pre-anthropogenic $\mathrm{Pb}$ in the oceans has also been terrigeneous in origin. Although $\mathrm{Pb}$ has a shorter residence time than $\mathrm{Nd}$ it can obviously also be advected on the basin scale depending on the residence times of the respective water masses (Abouchami and Goldstein 1995; Abouchami et al 1998). This implies that $\mathrm{Pb}$ isotope time series in a particular crust, similar to $\mathrm{Nd}$ isotopes, reflect potential changes in input as well as in circulation. In this section those parts of the records which most clearly reflect changes in erosional inputs to the oceans and their significance will be reviewed.

\subsection{Neodymium}

- Erosion of the continents and the input of the erosion products into the oceans, either as particulates (including atmospheric dust) or as part of the dissolved river load are the ultimate source of $\mathrm{Nd}$ present in the crusts.

- The most spectacular shifts in $\varepsilon_{\mathrm{Nd}}$ in any of the time series occurs in the two western N. Atlantic crusts (Burton et al 1997; O'Nions et al 1998). Over the last few Ma they have shifted from the long-term (50 Ma) characteristic $\varepsilon_{\mathrm{Nd}}$ value of the N. Atlantic of $\sim-10$ by approximately $3 \varepsilon_{\mathrm{Nd}}$ units to $\varepsilon_{\mathrm{Nd}}=$ -13.5 , which is the characteristic value for NADW in the present day Atlantic (e.g. Piepgras and Wasserburg 1987). The contribution which is responsible for this unradiogenic $\mathrm{Nd}$ isotope composition of NADW is known to be located in the Labrador Sea (Stordal and Wasserburg 1986; Piepgras and Wasserburg 1987). This is the only known source where water masses with $\varepsilon_{\mathrm{Nd}}$ values $<-20$ are found.

There are two possibilities for the cause of the dramatic shift of $\varepsilon_{\mathrm{Nd}}$ in the western N. Atlantic. The first is that there was no change at all in the amount and composition of $\mathrm{Nd}$ delivered to the oceans by erosion over the last 5 to $10 \mathrm{Ma}$. In this case the shift in $\varepsilon_{\mathrm{Nd}}$ would be due to an intensification of deep water generation in the Labrador Sea and as a consequence an increased amount of $\mathrm{Nd}$ with a low $\varepsilon_{\mathrm{Nd}}$ value contributing to NADW (Burton et al 1997). The second possibility is that amount and composition of the $\mathrm{Nd}$ input did change in a way expected to have accompanied the onset of the Northern Hemisphere Glaciation. It is has been shown that prior to ca. $3 \mathrm{Ma}$ ago the amount of erosional input in the Labrador Sea region was small (Shackleton et al 1984; Raymo 1994) and it has also been suggested that deep water formation in the Labrador Sea region may have been much less important before about $3 \mathrm{Ma}$ than afterwards (Burton et al 1997). Von Blanckenburg and O'Nions (1999) have argued that the constant ${ }^{10} \mathrm{Be} /{ }^{9} \mathrm{Be}$ ratio in the N. Atlantic seawater over this time period requires that the balance between terrigeneous ${ }^{9} \mathrm{Be}$ 

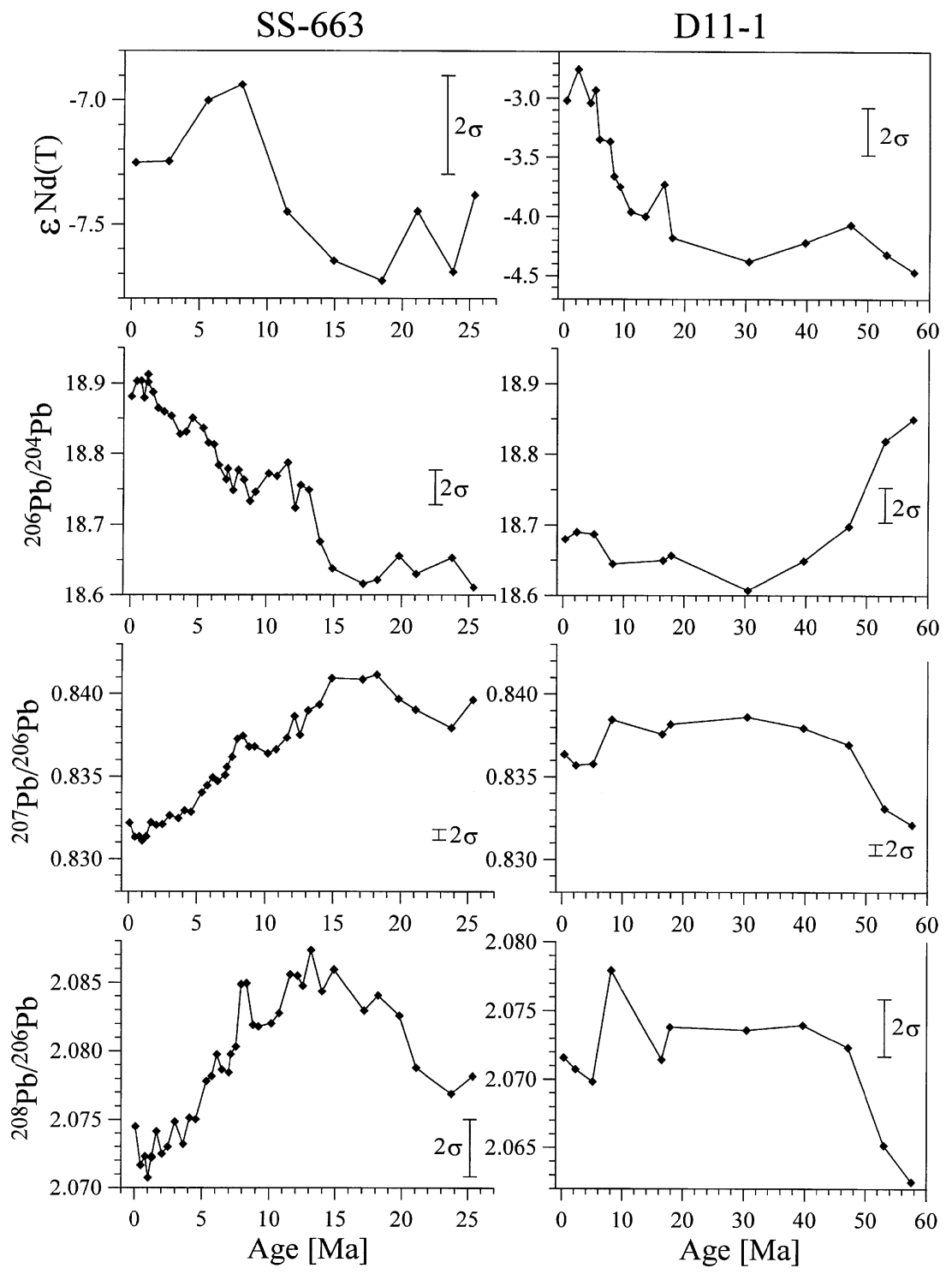

Figure 5. Comparison of $\varepsilon_{\mathrm{Nd}}$ (age corrected) and Pb isotope time series for crusts SS-663 (O'Nions et al 1998; Frank and O'Nions, 1998 ) and D11-1 (Ling et al 1997) based on the ${ }^{10} \mathrm{Be} /{ }^{9} \mathrm{Be}$ chronologies given in figure 1 . Note the ${ }^{208} \mathrm{~Pb} /{ }^{206} \mathrm{~Pb}$ structure in SS-663 which has been related to the uplift and erosion of the Himalyas (Frank and O'Nions 1998).

input and cosmogenic ${ }^{10} \mathrm{Be}$ input into the N. Atlantic remained fixed in which case a change in the integrated $\varepsilon_{\mathrm{Nd}}$ value of the terrigeneous input into the N. Atlantic is more likely as a cause for the observed isotopic shifts than a change in circulation. Thus, there appears to be a close link between the Quaternary glaciation and the input of Nd with highly unradiogenic isotope composition in the area of the Labrador Sea. This is supported by results of Winter et al (1997) on ferromanganese micronodules from marine sediments in the Arctic Ocean which also show a major shift in $\varepsilon_{\mathrm{Nd}}$ towards more negative values around $2 \mathrm{Ma}$ ago.

A second point concerns the approximately contemporaneous shift in $\varepsilon_{\text {Nd }}$ towards more unradiogenic values evident in the time series of crusts from the Pacific. Although these effects are more subtle with $\varepsilon_{\mathrm{Nd}}$ varying by only 1 unit or less they are nevertheless significant (Ling et al 1997). It was initially suggested that the overall increase in $\varepsilon_{\mathrm{Nd}}$ from 20 to around to $5 \mathrm{Ma}$ ago in the Pacific crusts may have been arrested by an increased influx of water from the Antarctic Circumpolar Current (ACC) in combination with an intensification of NADW production which enhanced the transfer of unradiogenic $\mathrm{Nd}$ from the North Atlantic into the Pacific Ocean via the ACC (Ling et al 1997; Burton et al 1997). Later missing evidence for a trend towards more unradiogenic $\mathrm{Nd}$ in a crust that has grown from ACC water (O'Nions et al 1998) has suggested that this was not the case and that the unradiogenic trend in the Pacific crusts since about 3-5 Ma ago may have been caused by regional changes of $\mathrm{Nd}$ sources in the Pacific. This is also suggested by the approximately contemporaneous changes in $\mathrm{Pb}$ isotopes in the Pacific crusts which trend towards more Pacific-type values (Ling et al 
1997; Christensen et al 1997) and can not be explained by any kind of contribution from the N. Atlantic.

\subsection{Lead}

$\mathrm{Pb}$ is advected over shorter lengthscales than $\mathrm{Nd}$ in the oceans because it is more particle reactive. Nevertheless there is a very close correspondence between the $\mathrm{Pb}$ and $\mathrm{Nd}$ isotope time series in some crusts such as those from the western N. Atlantic. It is thus likely that there is a straightforward connection between these isotopic changes and a change in the source of terrigeneous erosion products or a change in circulation. In the specific case of the western N. Atlantic crusts the isotope time series of both $\mathrm{Nd}$ and $\mathrm{Pb}$ apparently recorded changes in the erosional input into NADW.

Crust SS-663 from the central Indian Ocean provides another good illustration of the way in which the crusts record changes of erosion inputs into the ocean (O'Nions et al 1998; Frank and O'Nions 1998). The $\varepsilon_{\mathrm{Nd}}$ and $\mathrm{Pb}$ isotope time series for SS-663 are compared in figure 5 . The first point to note is that $\varepsilon_{\mathrm{Nd}}$, the variation of which is barely outside the assigned experimental error, shows a minimum between 19 and $15 \mathrm{Ma}$ ago and a shift towards more positive values $8 \mathrm{Ma}$ ago. The structure in the $\mathrm{Pb}$ isotope time series is much better resolved, particularly for ${ }^{207} \mathrm{~Pb} /$ ${ }^{206} \mathrm{~Pb}$ and ${ }^{208} \mathrm{~Pb} /{ }^{206} \mathrm{~Pb}$ ratios. In the latter case the ${ }^{208} \mathrm{~Pb} /{ }^{206} \mathrm{~Pb}$ ratios are the highest observed in the ocean so far and show a pronounced maximum between 20 and $15 \mathrm{Ma}$ ago. Frank and O'Nions (1998) have suggested that the $\mathrm{Pb}$ with this unusual isotopic composition has been derived from the products of Himalayan erosion and that the maximum values correspond to the period of maximum uplift rate. If this interpretation is correct then it is perhaps surprising that the $\varepsilon_{\mathrm{Nd}}$ signal is so damped in the record of SS-663, particularly given that the Himalayan erosion products as preserved in the Bengal Fan have a low and relatively uniform $\varepsilon_{\mathrm{Nd}}$ of around $-16 \pm 2$ (Derry and France-Lanord 1996). There may be three contributing factors responsible for this observation. The first is that no deep water has been generated in the northern Indian Ocean and, unlike the Labrador Sea area, there has not been a direct route for the transfer of an isotopic signal from surface waters to deep water in the northern Indian Ocean. The second factor is the low $\mathrm{Pb} / \mathrm{Nd}$ ratio of seawater compared with the anticipated much higher ratio in particulates produced by erosion of the Himalayas: interaction between seawater and such particulates may have had a more profound effect on dissolved $\mathrm{Pb}$ than Nd (Frank and O'Nions 1998). The third factor may be that a $\mathrm{Pb}$ isotope signal from the Himalayas is scavenged more efficiently than Nd due to the higher particle reactivity of $\mathrm{Pb}$ and was thus recorded close to the source of input whereas an $\mathrm{Nd}$ signal may have been mixed and diluted.

\section{Influence of gateway and circulation changes}

The establishment of the Antarctic Circumpolar Current (ACC) following the opening of the Drake passage between Antarctica and South America about $23 \mathrm{Ma}$ ago (Barker and Burrell 1977) was a key prerequisite on the way to the contemporary pattern of the global thermohaline circulation. The more recent closure of the Panama Gateway has been considered an important factor in further moderating this global circulation pattern. Modelling has suggested that unrestricted exchange of low salinity Pacific water masses with the Atlantic and the contemporaneous wind-forced flow of high salinity Atlantic surface waters into the Pacific prevented the formation of NADW deep water (Meier-Reimer et al 1990). Since $12 \mathrm{Ma}$ ago the throughflow became increasingly restricted (Keller and Barron 1983; Duque-Caro 1990) with some indication for a transient landbridge as early as 9.3-8 Ma ago (Marshall 1985). The consequent redirection of the saline Carribean Current to the north contributed to an increase of the strength of the Gulf Stream (Kaneps 1979) thus increasing the salinity and heat transfer to the North Atlantic. Cooling of this highly saline surface water enabled the production of deep water in the N. Atlantic to start, probably as early as 10 Ma ago (Woodruff and Savin 1989; Delaney 1990). Support for a further enhancement of NADW flow at 3-4 Ma was deduced from sediment accumulation patterns on drifts in the North Atlantic (Wold 1994) and Atlantic versus Pacific benthic foraminiferal carbon isotope gradients (Raymo et al 1990; Billups et al 1998). Final establishment of the modern circulation mode was suggested to have been in principle completed by $4.6 \mathrm{Ma}$ (Haug and Tiedemann 1998; Driscoll and Haug 1998). The $\varepsilon_{\mathrm{Nd}}$ and $\mathrm{Pb}-$ isotope records of ferromanganese crusts summarised above may provide some further insights into these effects.

The opening of the Drake Passage is not reflected by any shifts in the $\mathrm{Nd}$ or $\mathrm{Pb}$ isotope time series in the Atlantic and Pacific crusts analysed so far. Although none of the Atlantic and Pacific crusts available which cover the period of this event is located close to the Passage the observation is surprising given the large changes in ocean circulation that presumably occurred.

A similar conclusion arises for the effects of the closure of the Panama Gateway. Whereas final closure at about $3 \mathrm{Ma}$ ago must have affected the exchange of surface and shallow waters between the Atlantic and Pacific Oceans, the complex archipelagic character of the Gateway and missing precise bathymetric data make it difficult to estimate how and when water mass exchange between the Atlantic and Pacific was affected. The marked change of the $\mathrm{Pb}$ and $\mathrm{Nd}$ isotope time series in the western N. Atlantic at about 3-4 Ma ago was suggested to be linked to the final closure 
through an increase in production of deep water in the Labrador Sea (Burton et al 1997). However, the onset of northern hemisphere glaciation at about 3.2-2.6 Ma ago (Shackleton et al 1984; Raymo 1994) was responsible for a large increase in supply of unradiogenic $\mathrm{Nd}$ and radiogenic $\mathrm{Pb}$ at about the same time (O'Nions et al 1998; Frank and O'Nions 1998; von Blanckenburg and O'Nions 1999). In addition, it was shown that similar patterns in $\mathrm{Nd}$ and $\mathrm{Pb}$ isotope time series have occurred in the Arctic Ocean (Winter et al 1997) which suggests that the increased input of detrital material was the dominant process.

A trend towards more radiogenic Nd-isotopic composition starting around $12 \mathrm{Ma}$ in the equatorial Pacific isotope records may have been caused by a decreasing supply of unradiogenic $\mathrm{Nd}$ from the Atlantic to the Pacific due to the shallowing of the Panama Gateway and the subsequent change of the trend towards more unradiogenic Nd may be related to the intensification of the global thermohaline circulation (Burton et al 1997). However, this change of the trend must have been caused by the transfer of a signal via the thermohaline circulation for which there is no evidence in crusts from the ACC and the central Indian Ocean (O'Nions et al 1998). It appears therefore that the closure of the Panama isthmus and the associated circulation changes have together left a surprisingly small imprint on the $\mathrm{Nd}$ and $\mathrm{Pb}$ isotopic composition of the deep water and that the change of provenance and supply of detrital material has been the dominating process controlling dissolved $\mathrm{Nd}$ and $\mathrm{Pb}$ in the deep ocean.

\section{Concluding remarks}

The $\mathrm{Nd}$ and $\mathrm{Pb}$ isotope time series of well-dated crusts from the Atlantic, Indian and Pacific Oceans have retained a remarkable record of deep water mass compositions in some cases back to $60 \mathrm{Ma}$. It is suggested that the $\mathrm{Nd}$ and $\mathrm{Pb}$ isotope record through time has been mainly controlled by variations of composition and amount of terrigeneous inputs into the oceans and their dispersal by the ocean circulation. Major events suggested to be recorded in the isotope time series are Himalayan uplift and erosion and the Northern Hemisphere Glaciation. The records in the Atlantic and Pacific crusts show little unambiguous evidence for circulation changes which accompanied the opening of the Drake Passage and the start of the circumAntarctic circulation as well as the closure of major oceanic gateways such as Panama.

The isotope records in the ferromanganese crusts are expected to provide further information on more subtle shifts in water mass distribution. Of particular interest will be crusts located over a range of depths at a particular locality, which will be sensitive to vertical shifts in the positions of different water masses.

\section{Acknowledgements}

This research was supported by a grant to MF from the EU within the TMR network "The Marine Record of Continental Tectonics and Erosion". Friedhelm von Blanckenburg is thanked for permission to use a modified version of figure 2 .

\section{References}

Abouchami W and Goldstein S L 1995 A lead isotopic study of Circum-Antarctic manganese nodules; Geochim. Cosmochim. Acta 59 1809-1820

Abouchami W, Goldstein S L, Galer S J G, Eisenhauer A and Mangini, A 1997 Secular changes of lead and neodymium in central Pacific seawater recorded by a Fe-Mn crust; Geochim. Cosmochim. Acta 61 3957-3974.

Abouchami W, Galer S J G and Koschinsky A. 1998 Pb and $\mathrm{Nd}$ isotopes in NE Atlantic Fe-Mn crusts: proxies for trace metal paleosources and paleocean circulation; Geochim. Cosmochim. Acta (in press)

Albarède F and Goldstein S L 1992 World map of Nd isotopes in sea-floor ferromanganese deposits; Geology 20 761-763

Albarède F, Goldstein S L and Dautel D 1997 The neodymium isotopic composition of manganese nodules from the Southern and Indian Oceans, the global oceanic neodymium budget, and their bearing on deep ocean circulation; Geochim. Cosmochim. Acta 61 1277-1291

Banakar V K and Borole D V 1991 Depth profiles of ${ }^{230} \mathrm{Th}_{\text {excess}}$, transition metals and mineralogy of ferromanganese crusts of the Central Indian basin and implications for paleoceanographic influence on crust genesis; Chem. Geol. 94 33-44

Barker P F and Burrell J 1977 The opening of Drake Passage; Mar. Geol. 25 15-34

Belshaw N S, O'Nions R K and von Blanckenburg F 1995 A SIMS technique for ${ }^{10} \mathrm{Be} /{ }^{9} \mathrm{Be}$ measurement in environmental materials; Int. J. Mass Spectrom. Ion Proc. 142 55-67

Billups K, Ravelo A C and Zachos J C 1998 Early Pliocene deep water circulation in the western equatorial Atlantic: implications for high-latitude climate change; Paleoceanography 13 84-95

Bollhöfer A, Eisenhauer A, Frank N, Pech D and Mangini A 1996 Thorium and uranium isotopes in a manganese nodule from the Peru basin determined by alpha sectrometry and thermal ionization mass spectrometry (TIMS): Are manganese supply and growth related to climate?; Geol. Rundsch. 85 577-585

Burton K W, Ling H-F and O'Nions R K 1997 Closure of the Central American Isthmus and its effect on deep-water formation in the North-Atlantic; Nature 386 382-385

Chabaux F, Cohen A S, O'Nions R K and Hein J R 1995 ${ }^{238} \mathrm{U}_{-}^{234} \mathrm{U}_{-}{ }^{230} \mathrm{Th}$ chronometry of Fe-Mn crusts: Growth processes and recovery of thorium isotope ratios of seawater. Geochim. Cosmochim. Acta; 59 633-638

Chabaux F, O'Nions R K, Cohen A S and Hein J R 1997 ${ }^{238} \mathrm{U}_{-}{ }^{234} \mathrm{U}_{-}{ }^{230} \mathrm{Th}$ disequilibrium in hydrogenous oceanic $\mathrm{Fe}-$ Mn crusts: Paleoceanographic record or diagenetic alteration?; Geochim. Cosmochim. Acta 61 3619-3632

Christensen J N, Halliday A N, Godfrey L V, Hein J R and Rea D K 1997 Climate and ocean dynamics and the lead isotopic records in Pacific ferromanganese crusts; Science 277 913-918

Delaney M L 1990 Miocene benthic foraminiferal $\mathrm{Cd} / \mathrm{Ca}$ records: South Atlantic and Western Equatorial Pacific; Paleoceanography 5 743-760

DePaolo D J 1986 Detailed record of Neogene Sr isotopic evolution of seawater from DSDP site 590B; Geology; 14 103-106 
Derry L A and France-Lanord C 1996 Neogene Himalayan weathering history and river ${ }^{87} \mathrm{Sr} /{ }^{86} \mathrm{Sr}$ : impact on the marine Sr record; Earth Planet. Sci. Lett. 142 59-74

Driscoll N W and Haug G H 1998 A short circuit in the thermohaline circulation: A cause for northern hemisphere glaciation; Science $\mathbf{2 8 2}$ 436-438

Duque-Caro H 1990 Neogene stratigraphy, paleoceanography and paleobiogeograpy in northwest South America and the evolution of the Panama Seaway; Palaeogeog. Palaeoclimatol. Palaeoecol. 77 203-234

Eisenhauer A, Gögen K, Pernicka E, and Mangini A 1992 Climatic influences on the growth rates of Mn crusts during the late Quaternary; Earth Planet. Sci. Lett. 109 25-36

Frank M. and O'Nions R K 1998 Sources of $\mathrm{Pb}$ for Indian Ocean ferromanganese crusts: A record of Himalayan erosion?; Earth Planet. Sci. Lett. 158 121-130

Frank M, O'Nions R K, Hein J R and Banakar V K 199960 Ma records of major elements and $\mathrm{Pb}-\mathrm{Nd}$ isotopes from hydrogenous ferromanganese crusts: Reconstruction of seawater paleochemistry. Geochim. Cosmochim. Acta, (accepted.)

Goldstein S L and O'Nions R K 1981 Nd and Sr isotopic relationships in pelagic clays and ferromanganese deposits; Nature 292 324-327

Halbach P, Segl M, Puteanus D and Mangini A 1983 Co-fluxes and growth rates in ferromanganese deposits from central Pacific seamount areas; Nature 304, 719-722.

Haug G H and Tiedemann R 1998 Influence of Panamanian Isthmus formation on Atlantic Ocean thermohaline circulation; Nature 393 673-676

Hess J, Bender M L and Schilling J G 1986 Seawater ${ }^{87} \mathrm{Sr} /{ }^{86} \mathrm{Sr}$ evolution from Cretaceous to present; Science 231 979-984

Hodell D A, Mueller P A and Garrido J R 1991 Variations in strontium isotopic compositions of seawater during the Neogene; Geology 19 24-27

Jeandel C 1993 Concentration and isotopic composition of $\mathrm{Nd}$ in the South Atlantic Ocean; Earth Planet. Sci. Lett. 117 581-591

Kaneps A G 1979 Gulf Stream: Velocity fluctuations during the late Cenozoic; Science 204, 297-301

Keller G and Barron J A 1983 Paleoceanographic implications of Miocene deep-sea hiatuses; Geol. Soc. Am. Bull. 94 590-613

Koepnick R B, Burke W H, Denison R E, Hetherington E A, Nelson H F, Otto J B and Waite L E 1985 Construction of the seawater ${ }^{87} \mathrm{Sr} /{ }^{86} \mathrm{Sr}$ curve for the Cenozoic and Cretaceous; Chem. Geol. 58 55-81

Levitus S 1982 Climatological Atlas of the world ocean; NOAA Prof. Pap. 13 1-173

Ling H-F, Burton K W, O'Nions R K, Kamber B S, von Blanckenburg F, Gibb A J and Hein J R 1997 Evolution of $\mathrm{Nd}$ and $\mathrm{Pb}$ isotopes in Central Pacific seawater from ferromanganese crusts; Earth Planet. Sci. Lett. 146 1-12

Manheim F T 1986 Marine cobalt resources; Science 232 600-608

McMurtry G M, VonderHaar D L, Eisenhauer A, Mahoney J J and Yeh H-W 1994 Cenozoic accumulation history of a Pacific ferromanganese crust; Earth Planet. Sci. Lett. 125 105-118

Marshall L G 1985 Geochronology and land-mammal biochronology of the transamerican faunal interchange; in $\mathrm{F} G$ Stehli and S D Webb (eds), The Great American Biotic Interchange, (New York: Plenum Press) 49-85.

Meier-Reimer E, Mikolajewicz U and Crowley T 1990 Ocean general circulation model sensitivity experiment with an open central American isthmus; Paleoceanography 5 349-366

Michard A, Albarède F, Michard G, Minster J F and Charlou J L 1983 Rare-earth elements and uranium in high-temperature solutions from East Pacific Rise hydrothermal vent field $\left(13^{\circ} \mathrm{N}\right)$; Nature 303 795-797
Neff U, Bollhöfer A and Mangini A 1998 Explaining discrepant depth profiles of ${ }^{234} \mathrm{U} /{ }^{238} \mathrm{U}$ and ${ }^{230} \mathrm{Th}_{\mathrm{ex}}$ in Mn-crusts; Mineral. Mag. 62A 1064-1065 (abstr.).

O'Nions R K, Frank M, von Blanckenburg F and Ling H.-F 1998 Secular variation of $\mathrm{Nd}$ and $\mathrm{Pb}$ isotopes in ferromanganese crusts from the Atlantic, Indian and Pacific Oceans Earth Planet. Sci. Lett. 155 15-28

Piepgras D J, Wasserburg G J and Dasch E J 1979 The isotopic composition of $\mathrm{Nd}$ in different ocean masses; Earth Planet. Sci. Lett. 45 223-236

Piepgras D J and Wasserburg G J 1982 Isotopic composition of neodymium in waters from the Drake Passage; Science $\mathbf{2 1 7}$ 207-214

Piepgras D J and Wasserburg G J 1985 Strontium and neodymium isotopes in hot springs on the East Pacific Rise and Guyamas Basin; Earth Planet. Sci. Lett. 72 341-356

Piepgras D J and Wasserburg G J 1987 Rare earth transport in the western North Atlantic inferred from isotopic observations; Geochim. Cosmochim. Acta 51 1257-1271

Puteanus D and Halbach P 1988 Correlation of Co concentration and growth rate - A method for age determination of ferromanganese crusts; Chem. Geol. 69 73-85

Raymo M E, Ruddiman W F, Shackleton N J and Oppo D W 1990 Evolution of Atlantic-Pacific $\delta^{13} \mathrm{C}$ gradients over the last 2.5 m.y; Earth Planet. Sci. Lett. 97 353-368

Raymo M E 1994 The initiation of northern hemisphere glaciation; Annu. Rev. Earth Planet. Sci. 22 353-383

Schaule B K and Patterson C C 1981 Lead concentrations in the north Pacific: evidence for global anthropogenic perturbations; Earth Planet. Sci. Lett. 54 97-116

Segl M, Mangini A, Bonani G, Hofmann H J, Nessi M, Suter M, Wölfli W, Friedrich G, Pluger W L, Wiechowski A and Beer J $1984{ }^{10}$ Be dating of a manganese crust from Central North Pacific and implications for oceanic paleocirculation; Nature 309 540-543

Shackleton, N J, Backman J, Zimmermann H, Kent V D, Hall M A, Roberts D G, Schnitker D, Baldauf J G, Desprairies A, Homrighausen R, Huddleston P, Keene J B, Kaltenbach A J, Krumsiek K A O, Morton A C, Murray J W and WestbergSmith W J 1984 Oxygen calibration and the onset of icerafting and history of glaciation in the North Atlantic region; Nature 307 620-623

Stordal M C and Wasserburg G J 1986 Neodymium isotopic study of Baffin Bay water: sources of REE from very old terranes; Earth Planet. Sci. Lett. 77 259-272

von Blanckenburg F, O'Nions R K, Belshaw N S, Gibb A and Hein J R 1996a Global distribution of beryllium isotopes in deep ocean water as derived from Fe-Mn crusts; Earth Planet. Sci. Lett. 141 213-226

von Blanckenburg F, O'Nions R K and Hein J R 1996b Distribution and sources of pre-anthropogenic lead isotopes in deep ocean water from Fe-Mn crusts; Geochim. Cosmochim. Acta 60 4936-4957

von Blanckenburg F and O'Nions R K 1999 Response of beryllium and radiogenic isotope ratios in northern Atlantic deep water to the onset of Northern Hemisphere Glaciation; Earth Planet. Sci. Lett. (accepted)

Winter B, Johnson C M and Clark D L 1997 Strontium, neodymium and lead isotope variations of authigenic silicate sediment components from the Late Cenozoic Arctic Ocean: Implications for sediment provenance and the source of trace metals in sea water; Geochim. Cosmochim. Acta $\mathbf{6 1}$ 4181-4200

Wold C N 1994 Cenozoic sediment accumulation on drifts in the North Atlantic; Paleoceanography 9 917-941

Woodruff F and Savin S M 1989 Miocene deepwater oceanography; Paleoceanography 4 87-140 